http://dx.doi.org/10.12775/szhf.2014.003

\title{
Rzut oka na celne zasady nauki obyczajów od wieku Arystotelesa aż do Kanta przez Chrystiana Garwe
}

\section{CZĘŚĆ VII}

Teraz dla ułatwienia sobie pracy $\mathrm{w}$ przedstawieniu coraz bardziej pomnażających się w naszych wiekach nowych moralności zasad i systematów wszystkie ile można pod dwie główne klasy podciągnę. Część naszych filozofów, a mianowicie filozofowie angielscy, usiłowali całą moralność oprzeć na uczuciu, czyli władzy uczucia w człowieku. Inni, a mianowicie filozofowie niemieccy, wyciągnęli moralność z wyobrażeń i rozumu człowieka. Systema przez Leibniza i Wolffa utworzone oba te źródła moralności połączyć usiłowano, kiedy doskonałość założyły za cel ostateczny człowieka i kiedy przepis dążyć nieustannie ku własnej swojej doskonałości ogłosiły za pierwszą całej moralności zasadę.

\section{Pierwsza klasa}

Zasady z uczucia, czyli władzy uczucia w człowieku wyprowadzone

W tej klasie umieszczam najprzód systema miłości własnej, takie jakie od wielu francuskich filozofów za jedynie prawdziwe od płonnych wyrazów i wikłających rozumowań oswobodzone utrzymywanym było, a które Fry- 
deryk Drugi w osobnym małym piśmie bronić przedsięwziął. Ta zasada nie różni się wcale od systematu szczęśliwości: atoli ale obowiązku wyrazu miłość samego siebie, tudzież dla nieoznaczonych wyobrażeń, które łączą do niego filozofowie, powątpiewać można, czy to ma być systema właściwie Epikurejskie, które szczęśliwość człowieka na samych rozkoszach zmyślnych zakłada; czyli też systema prawdziwej i godnej człowieka szczęśliwości, które najcelniej na zdrowie, pomyślność, ukształtowanie całego człowieka, tak co od umysłu jako i ciała pogląda i miłości samego siebie rozleglejszy okręg naznacza. Filozofowie francuscy miłość samego siebie w pierwszym po większej części biorą znaczeniu. Aż pomiędzy nich żaden Epikureizmu do wyższego nie posunął stopnia albo raczej żaden go bardziej nie skoncentrował nad Helvetiusa, który wszystkie uciechy zmyślne do jednej miłości zmyślnej odnosi i z niej samej wszystko talenta, dowcip i cnotę szczególnie wyprowadza. Żadne atoli nad niego w piękniejszą go postać nie przybrał, żaden nie połączył z tylu dowcipnymi prawdziwymi po większej części i najprzyjemniej wyłożonymi postrzeżeniami z towarzyskiego pożycia ludzi czerpanymi i stąd też to systema stało się wkrótce systematem moralności powszechnie we Francji panującym.

Fryderyk Drugi uważał miłość samego siebie w drugim znaczeniu i rozumiał przez nie rzetelną, trwałą i właściwą szczęśliwość. Nie ma żadnej potrzeby dla której nad tym systematem, czyli w pierwszym czy w drugim rozumieniu wziętym miałbym zastanawiać się dłużej.

Do tej klasy należy także systema powszechnej ku ludziom miłości, które filozofowie angielscy, a osobliwie Szkoccy przyjęli i na pierwszą zasadę moralności zamienili. Ci uważają, że staranność człowieka o własne swoje uszczęśliwienie przedsięwzięta jedynie dla tegoż uszczęśliwienia zasługuje tylko na niwie roztropności, a że troskliwość jego o dobro innych sama szczególnie jest cnotą i że ponieważ człowiek nie jest w sobie zupełną i osobną całością, ale raczej częścią większego nierównie ogółu to jest w społeczeństwa ludzkiego temuż w społeczeństwu cały się odda i poświęcić obowiązany i że stąd podług wyrazu Cycerona część jedna jego osoby u jego czasu należy do własnej jego familii, druga do przyjaciół, trzecia do ojczyzny, a czwarta do całego rodu ludzkiego. Ci przydają, że powinności człowieka względem samego siebie ścisłym bardzo związkiem $\mathrm{z}$ tego wynikają systematu ponieważ człowiek niezdrowy, skaleczony i cierpiący na ciele, człowiek nieukształconego 
rozumu, a niespokojnego serca, człowiek pozbawiony dostatku i majątku nie może przyzwoicie społeczności służyć.

Utrzymuję po wtóre, że miłość ku innym ludziom jest pierwiastkową natury ludzkiej, własnością nadaną jej od twórcy, aby służyła za podstawę moralności całej. Łatwo poznać, iż zasada miłości ludzi wychodzi niemal na zasadę towarzyskiego pożycia, w tym od niej tylko różna, że tu działa szczególnie czyste uczucie serca, przez które człowiek cnotliwy, czyniąc dobrze ludziom, żadnej od nich nie oczekuje nagrody, w zasadzie zaś towarzyskiego pożycia zamyka się koniecznie wyobrażenie rozumu, wystawiające człowiekowi nieuchronną potrzebę łączenia się w społeczność z innymi ludźmi, aby mógł przyzwoicie umysł i ciało swoje ukształcić i być prawdziwie szczęśliwym. Atoli obydwie zasady jednym ulegają niedostatkom, najprzód iż przymiot pochodzący $\mathrm{z}$ innych wystawia się za pierwiastkowy przymiot natury ludzkiej, po wtóre iż obierają jedne cnotę i te zakładają za źródło i podstawę cnót innych, kiedy obiecali powszechną podać zasadę i powszechne źródło cnót wszystkich.

Jako Helvetius systema Epikura do najwyższego stopnia posunął, tak Hutcheson profesor filozofii moralnej w Glasgow, mąż zacny i prawdziwie wielki filozof ${ }^{1}$, systema uczucia w największej rozległości wyłożył, przypuszczając w naturze ludzkiej osobną władzę, przez którą by człowiek moralne dobro od złego moralnego, prawo od bezprawia rozróżniał widokiem pierwszego mile był widokiem drugiego dręczonym. On był pierwszym, który pomiędzy Szkockimi filozofami w dwóch mianowicie uniwersytetach Edynburskim i Glasgowskim zaprowadził zwyczaj, każdemu znakomitszemu i na pierwsze oko rzucenie niemogącemu być wytłumaczonym natury ludzkiej działaniu osobnej wyznaczaniu władzy, zwyczaj przeciwny filozofii spekulacyjnej lub filozofią praktyczną i na postrzeżeniu opartą, w której szczególniej celować usiłują Szkoccy filozofowie do wysokiego stopnia posunąć zdatny. Z pod którego pióra wyszło niemieckie dzieło o władzy poznawania w człowieku przypuszcza osobną władzę w naturze ludzkiej odnoszącą się

${ }^{1}$ Dzieło o namiętnościach i dzieło, w którym właściwie systema swoje rozwinął, jego celnymi mnie wiadomymi dziełami. Już to samo wielkie o nim wyobrażenie nie obudza, iż Adam Smith, który po nim na katedrę filozofii moralnej w Glasgow nastąpił, z wysokim zawsze o nim jako nauczycielu swoim mówił szacunkiem i poczytnie sobie za wielki zaszczyt, iż akademia godnym go być uznała do zastąpienia miejsca po tym tak wielkim mężu. 
do udzielania innym myśli własnych, a osobną do wynajdywania słów i wyrazów. Ale nawet Smith, w wielu innych względach tak prawdziwy i głęboko myślący, nie był ze wszystkim od tej wady wolnym, kiedy na początku sławnego dzieła o bogactwach narodowych przypuszcza zasadę zamiany, czyli osobną władzę, przez którą człowiek zdatnym jest i skłonnym do czynienia zamian. Tymczasem byłoby to w rzeczy samej wszelkiego badania i wyszukiwania pierwszych przyczyn, gdybyśmy każdemu skutkowi natychmiast osobną i pierwszą wyznaczali przyczynę i imieniem wziętym od skutku ją nazwali. Tym zaiste były tak nazwane qualitates occulta u Scholastyków, któremi tak bardzo się brzydzimy, a które w najoświeceńszym wieku i narodzie do szkół na nowo powracają. Atoli jak powiedziałem już wyżej wielka obfitość użytecznych wiadomości, które od metafizycznych spekulacji są nieporównanie ważniejsze, okrywa u wspomnianych dopiero mężów tę wadę, którą atoli wytknąć obowiązany byłem. Znajdowanie się w naturze ludzkiej osobnego zmysłu moralnego w żadnym sposobie być dowiedzionym nie może.

1. Przedmiot każdego zmysłu musi być czymś pojedynczym i niezłożonym, a moralność: a moralność jest czymś ogólnym i wiele w sobie obejmującym. Przez wrażenie od własnych naszych lub innych ludzi spraw na pewnym zmyśle uczynione moglibyśmy postrzec ich przyjemność lub nieprzyjemność, lecz żeby ta przyjemność koniecznie moralną być miała, tego żaden zmysł pokazać nam nie może. Przez oko czujemy przyjemność kolorów i przyjemność postaci. Atoli że przyjemność postaci należy do innego rodzaju u i nazywa się pięknością tego naucza rozum. Ucho nasze bawi się miłym brzmieniem pojedynczych głosów tudzież harmonią i melodią połączonych tonów. Że jednak to połączenie tonów, które składa muzyka należy do rodzaju wyższych uciech uszlachetniających nasz umysł, to jedynie rozum poznać może.

2. Gdyby człowiek czuł bezpośrednio osobnym zmysłem to wszystko, co jest prawym albo nieprawym, moralnie dobrym albo moralnie złym, natenczas w obyczajowym postępowaniu swoim miałby nierównie bezpieczniejszego wodza niżeli ma w rzeczy samej. Człowiek najcnotliwszy zostaje bardzo często w troskliwej niepewności co w obecnej chwili rzetelną dla niego jest powinnością. Dopiero po długim rozmyślaniu lub naradzeniu się z mądrym przyjacielem nabywa często wątpliwego względem tej rzeczy światła. Sprawa przedstawiona moralnemu zmysłowi nie czyni na nim żadnego ani przyjemnego ani nieprzyjemnego wrażenia. 
3. Okazaną jest rzeczą, że cnota powstaje z wyobrażeń, a każda powinność nie pierwej nam się okaże w prawdziwej swojej piękności aż przyzwoicie rozważoną zostanie. Lecz w każdym zmyśle uczucie przyjemności jest pierwszym, a uważanie przyczyn po nim dopiero następnie. Człowiek także wtenczas dopiero jest do moralności sposobnym, kiedy jego rozum do pewnego stopnia ukształconym został, a komu zbywa na tej ostatniej władzy, temu zbywać musi i na pierwszej. Lecz zmysły rozwijają się w człowieku pierwej niż wszystkie inne władze i znajdują się zawsze w grubej nawet i nieukształconej osoby.

4.

Zajmując się w tej chwili szkockimi filozofami, nie mogę nie wspomnieć dwóch zacnych mężów: Fergusona i Smitha, obu wybornych pisarzy, którzy moralne i polityczne umiejętności prawdziwie doskonałymi wzbogacili dziełami.

1. Ferguson ani w krótkim zbiorze moralności całej, ani w swojej historii społeczeństwa ludzkiego, ani w najnowszym dziele pod tytułem „Systema moralnych i politycznych umiejętności” - trzech pismach prawdziwie wybornych w tym rodzaju nie miał właściwego zamiaru wyszukiwania i utworzenia pierwszej moralności zasady; jego filozofia nie jest szczególnie na samym uczuciu opartą: atoli uważa najcelniej człowieka jako do społeczności stworzonego, a w prawdziwym duchu dawnych Rzymian i nowych Brytańczyków znajduje większą część powinności jego w patriotycznych postępkach w prawym staraniu się o dobro ludzi i obywateli; w całym zaś rozwinięciu systematu swojego tyle jest oryginalnym, iż zupełnie ode mnie być pominiętym nie może.

Systema Fergusona jest właściwie mówiąc systematem stoików od niepotrzebnych subtelności i przesadzenia oczyszczonym, a do swej istotnej treści zebranych, który na tym zależy: iż człowiek uszczęśliwienia swojego jedynie szukać powinien w nieprzerwanym doskonaleniu całej swojej natury i że ta doskonałość przez całe życie jego nie może inaczej być pomnażaną tylko przez ciągłe wykonywanie spraw dobroczynnych i patriotycznych, kierowanych męstwem i roztropnością. Właściwym Fergusonowi wyobrażeniem, jeżeli nie nowym zupełnie, to od nikogo pierwej dostatecznie nie objaśnionym jest uwaga, że człowiek równie jak wszystkie inne żywe i organiczne jestestwa, jest istotą nieprzerwanie postępującą i tylko w ciągu i następstwie czasu istniejącą, 
która nigdy razem nie jest zupełną i o której nigdy powiedzieć nie można: oto teraz już jest zupełnie doskonałą. Stąd wnosi Ferguson, iż ostatni cel człowieka nie zależy na oznaczonym jakowym i zupełnie spokojnym stanie jego, ale raczej na nieustannej czynności i ciągle pomnażającej się doskonałości jego. To wszystko, czego nabył już człowiek lub czego kiedykolwiek nabędzie, niczem innym nie jest jak tylko punktem spocznienia, gdzie on w podróży życia swojego do nowych i ważniejszych zamiarów wzmacniać się i gotować powinien. Na samym przeto działaniu, na działaniu doskonałość ludzkiej natury czynnie okazującym i rozwijającym, a tym samym na działaniu roztropnym, sprawiedliwym, umiarkowanym i mężnym zależy najwyższy cel i prawdziwe uszczęśliwienie człowieka. Te zasady wystawia Ferguson w tak dzielnym i męskim stylu, który jest niezaprzeczonym świadectwem zupełnego o nim przekonania jego, tudzież najwyższego przenikania się niemu i stosuje one do wszystkich moralnych i politycznych okoliczności, do których tylko zastosowanymi być mogą, iż we wszystkich dziełach swoich podaje filozofowi nowe myśli, a co w sercu moralisty nowe uniesienia obudza. Dokładniejsze ocenienie tego wszystkiego, co w systemacie Fergusona jest właściwym, byłoby nieużytecznym, ponieważ są to tylko szczególne zastosowania prawd ogólnych, o których już gdzie indziej mówiłem.

2. Adam Smith, najpierwszy z mych szkockich przyjaciół i nauczycielów, bardziej oryginalnie od Fergusona i we wszystkich naukach, około których pracował, ducha wynalazków okazujący, w dziele swym o uczuciach moralnych jedynym, w którym zmysłu o moralności traktuje, usiłuje wyłożyć nową nauki obyczajów zasadę i tę na rozumowaniach i licznych doświadczeniach oprzeć. Ta zasada, jeżeli można użyć tego wyrazu o pomysłach wielkiego i samego siebie myślącego filozofa, jest niedorzeczną i do obalenia najłatwiejszą. Atoli przez swoje objaśnienia i zastosowania tak ją robi uczącą; tak dobrze widzi rzeczy same, chociaż dla nadzwyczajnej postaci, w którą one przyodział, zdaje się nie bardzo przewrotnie poglądać, a rozwinięcie jego własnego systematu połączone docenieniem systematów obcych wnosi tak jasne światło w historię moralności i całą osnowę tej nauki, iż z jego dzieła o uczuciach ludzkich, którego pierwszą zasadę poczytnie za niedorzeczną więcej nierównie gruntownych myśli powziąłem niż z dzieł wielu innych filozofów mniej nagannych w swoich zasadach, w dowodach i rozumowaniach ściślejszych.

Tą zasadą jest sympatia. Człowiek tak za natury jest ukształcony, iż to wszystko, co którykolwiek drugi cierpi lub czyni żywym bierze w podział 
uczuciem. Wziął od natury pierwiastkową skłonność przenoszenia i umieszczania do pewnego stopnia samego siebie w drugiej osobie, z którą dzielny popęd czynienia tego skoro tylko $\mathrm{z}$ tą osobą jest $\mathrm{w}$ towarzystwie, a tym silniejszy im ta osoba bardziej jemu jest miłą. Jeżeli teraz umieściwszy samego siebie ile tylko mógł w drugiej osobie i przeniknąwszy żywo cały jej stan wewnętrzny postępowanie jej potwierdza za sprawiedliwe i przyzwoite uznaje, postępowanie to jest moralnie dobrym. Jeżeli zaś nie może przenieść samego siebie w uczucie drugiej osoby, ani powodów jej działania uznać za dobre, ponieważ tamte widzi być przesadzonymi, te zaś albo słabymi albo celowi swemu nie dosyć odpowiednimi, wtenczas postępowanie takowe za moralnie złe może sprawiedliwie poczytać.

Człowiek zaiste, który o drugim podług wspomnianej sądzić zamierza sympatii, chociażby nawet ten ostatni najlepszym był jego przyjacielem, jest zawsze sędzią bezstronnym. Nie może on czuć tego samego, co drugi w tym momencie czuje; może tylko żywo wyobrazić sobie, to co drugi w rzeczy samej czuje; serce jego wolnym jest od tych żądzy, które gwałtownie drugich miotają; może atoli w stosunkach i położeniu przyjaciela swojego poznać prawdziwe przyczyny tychże żądzy i dopuścić, aby te przyczyny na własne jego czucie działały. Jeżeli więc przy tej całej bezstronności i obojętności swojej postrzega, iż znaki, któremi drugi człowiek boleść albo rozkosz swoje wyraża, nie są zbyteczne, jeżeli postrzega, że środki użyte przez niego do ukojenia swych żądzy odpowiadają prawdziwej cenie przedmiotu i są stosowne do okoliczności: natenczas świadectwa jego można za ważne poczytać, a postępowanie osoby cierpiącej lub działającej uznać za umiarkowane, roztropne lub sprawiedliwe. Tysiąc przykładów dowodzi, że człowiek osoby siebie otaczające i spokojnie przyglądające się sprawom jego za sprawiedliwych sędziów postępowania swojego poczytuje. Usiłuje równie mocno przenieść samego siebie w położenie i uczucia drugich uważających stan i postępowanie jego jak ci ostatni usiłować mogli, aby z nim sympatyzowali; i sądzi że nie inaczej pozyska ich potwierdzenie jak kiedy w postępowaniu swoim prawdziwy stopnień mocy albo słabości znajdujących się w nim uczuć wyrazi. Czucia więc swoje w stosunku do rodzaju towarzystwa, w którym zostaje tudzież do mocniejszego lub słabszego, które toż towarzystwo w nich bierze albo podniesie albo poskromi. W boleściach ciała będzie się chronił krzyczenia i wszystkich gwałtownych niecierpliwości wybuchnień: ponieważ wie, że $\mathrm{w}$ tych boleściach bardzo mało inni ludzie mieć $\mathrm{z}$ nim mogą podziały, gdyż bardzo słabo w jego okoliczności i położeniu przenieść się mogą. W cierpieniach serca na przykład, gdy utracił jednego z pokrewnych albo z przyja- 
ciół nie będzie wstrzymywał potoku łez w gronie osób sprzyjających sobie, a pomiędzy osobami obojętnymi ku sobie, okaże tylko smutek spokojniejszy i cichy.

Prawidło moralne od stron obydwu to jat tak od osoby działającej jako i od tych, które na niego patrzą, zarówno uznane jest to, iż tak powinien postępować sobie, aby osoby nieumieszczone $\mathrm{w}$ położeniu jego nie przecięte jego uczuciami z nim atoli sympatyzować mogły: to jest tak sobie postępować powinien jak oddalony, a tym samym bezstronny spraw jego sędzia przyzwoitym być sądzi.

Któż atoli nie widzi na pierwsze oka rzucenie, że sympatyzowanie z drugiemi samo jest sprawą moralną, która koniecznie innego dla siebie prawidła i przepisu moralnego potrzebuje. Jeden człowiek nie jest zdatnym do tego samego udziału w uczuciach, losach i żądzach brata swojego, jak drugi. Sam Smith wyznaje iż mocniej sympatyzujemy z przyjaciółmi niźli z obcymi i że $\mathrm{w}$ jednym położeniu drugiej osoby lepiej się umieścić możemy niżeli $\mathrm{w}$ innym. Pomiędzy tymi różnymi stopniami sympatii, którym że osoba działająca właściwie kierować się powinna? Tego nigdzie Smith nie oznacza i wszystko równie jak pierwej własnemu rozsądkowi działającego jest zostawiony. Tymczasem to popularne i dosyć płytkie systema z jednego względu zgadza się zupełnie z wysokiem Kanta systematem.

Kant mówi: człowiek wtenczas dobrze czyni, kiedy owa maksyma, podług której on w pojedynczym i szczególnym przypadku postępuje sobie, na powszechną dla wszystkich ustawę zamienioną być może. Uważa przeto człowieka w dwóch odmiennych względach. Najprzód ile on jest umieszczonym w szczególnym i osobistym położeniu i do tego szczególnego i osobistego położenia jedynie w uwagach swoich ścieśnionym; po wtóre, ile dzielnością swego rozumu nad siebie samego nad świat i nad losy ludzkie się wznosi i nic osobistego, nic szczególnego nie czując. Sądzi o samym sobie i o wszystkich w ogólności ludziach i stosownie do tego sądu sprawę za dobrą albo za złą ogłasza. Wyrok wydany od niego w tej chwili podniesienia umysłu jest ustawą dla wszystkich, a maksymą obowiązującą dla niego samego. 